\title{
RAPID RURAL APPRAISAL, GENDER AND HEALTH ALTERNATIVE WAYS OF LISTENING TO NEEDS
}

Alice Welbourn

\section{INTRODUCTION}

Rapid Rural Appraisal (RRA) is a concept and methodology which has grown rapidly in its use in recent years. My own use of it began last year when conducting research for the Department of International Community Health of the Liverpool School of Tropical Medicine on the health needs of rural people in sub-Saharan Africa. In this work (Welbourn 1991a), RRA methods were used to identify the specific health issues affecting people in rural areas; and the relative value given to these health problems in comparison with other problems faced by these people. The work was conducted from a gender perspective, i.e. a perspective that recognises that women and men have different roles and experiences, which often result in their having different opinions, needs and options.

I was impressed by what I had learnt through using these techniques, compared with more conventional methods of qualitative data collection. I was also impressed by what I saw in the potential of using RRA methodology to train development workers to think differently.

It is one thing for us to theorize about gender and health: but it is often quite another to address these issues at grassroots level. Yet unless project field staff themselves have an understanding of the gender issues governing appropriate health care, there is little chance of the right kind of development work taking place.

I have decided therefore to use RRA as a tool for training development (including, but not exclusively health-) workers to think differently about their work. The two main objectives of the training courses have been:

$i$ to break down walls between the disciplines of health, education, agriculture, community development, etc. and

ii to build up a recognition that communities are diverse: that they are not homogeneous, passive units, but that they are highly structured, socio-economic systems. They are structured around various axes of difference, including gender, age, poverty, disability, ethnicity, etc. How these axes relate to each other varies in each context.

See RRA Notes for examples of developments and applications in recent years.
By using RRA techniques, it has been possible to persuade development workers, in a non-threatening manner, that both of these objectives are valid premises, fundamental to the success of their work.

Development workers are trained to become aware of these issues, firstly by studying material which has been collected from communities elsewhere in the world. They then have the opportunity themselves to collect and analyse similar material from their own area by employing these techniques. This learning by experience allows them to see for themselves what information can be learnt about their own locality, provided they are open to seeing and hearing it. It convinces them that what they have been taught is real fact and not just the machinations of an outsider trainer.

The rest of this article studies some of the information collected by using RRA techniques, and analyses the kind of understanding gained of rural health needs through this methodology. It should be pointed out that all the examples used were produced by nonliterate communities.

\section{STEP ONE: ANALYSIS OF DIFFERENCE}

The first step taken with the development workers is to encourage them to begin to recognise that communities are made up of a variety of different sub-groups, with different experiences, perspectives, interests and needs. For instance, poorer people, or those with less access to certain critical networks have different needs from those with higher status or more wealth. Women can have different needs from men and so on. The development workers are encouraged to recognise that poverty issues, age differences or gender can never actually be considered in entire isolation from other 'axes of difference'. The needs of a poor woman, for instance, may be quite different from those of a rich woman. Yet they are led through various exercises which enable them to perceive for themselves that these differences are there to be recognised if only we look for them and that their identification and analysis is fundamental to effective development.

An initial assumption made by most development workers, when asked to compare maps or charts produced by men and women, richer or poorer, is that those produced by the men or the richer (more educated) people are better. However, they are 
constantly encouraged to recognise this as a mere assumption and to challenge its validity. They gradually come round to acknowledging that the information is neither 'better' nor 'worse'. Instead they grow to realise that the information is just 'different', based on the perceptions of those whom they are asking. They also learn to recognise that it is always important to bear in mind what information is being sought and who would be the best interest group to ask. The workers finally recognise that current development planning really depends on a very limited perspective of need, often provided by elderly men alone.

Through this realisation development workers then recognise the basic necessity of having both men and women in their teams. There are many parts of the world where men just cannot speak to women at all and in most of the world the information that people give members of the opposite sex is influenced by the gender issue. So the training courses always consist of a mixed team of investigators, who can build up a mutual respect for each others' contribution. Women can then speak with women and men with men in the villages where the exercises are conducted. Whenever possible, groups are formed to talk with older and younger men separately as well. Ideally, older and younger women should be consulted separately too, but the reality of few female staff makes this division rarely possible.

Figures 1 and 2 provide an example of the different kind of information to be learnt about men and women, through using an exercise known as seasonal calendar construction. Women and men in the same village are asked, at separate meetings, to construct a calendar of events that occur in their lives over an annual cycle. The calendars are drawn on the ground, using stones, sticks, different coloured leaves, chalk or whatever is to hand. Piles are made in separate boxes, where each box represents a different month or season of the year, according to local terminology. The size of each pile reflects the amount of rainfall, or work done or so on for each period.

Figures 1 and 2, from Sierra Leone, illustrate the wide scope of information to be collected from such exercises. They reveal to us, the outsiders, the extent to which different resources and activities are linked into poverty and well-being.

The calendars illustrated in Figure 1 were constructed by people in a relatively well-to-do village, where rainfall is quite plentiful throughout the year, harvests are good, labour is hired from surrounding villages, debts are largely paid off and singing and dancing feature highly on the women's food availability and sickness charts. On the two calendars shown here, whilst the men consider themselves to have a break from work after the harvest period, women were at pains to illustrate how much work they continue to do throughout the year. However, overall, these charts give strong indications of the relative well-being in this village. The apparent paucity of reported sickness is clearly linked to the rest of the picture.

In contrast, good rain is absent from the charts of a nearby village, which is located in a rain shadow (see Figure 2). Poverty, ill-health, and worry feature much more strongly in the charts from this second village and with them a fair amount of family upheaval was also reported. Women in this village explained that nowadays they have to return to field labour just a week after child birth for fear of being beaten by their husbands. Men pointed out the months when quarrelling at home develops, and when some have to run away from the village for fear of being brought to court for non-payment of debt. In this village, women still have no time to rest; song and dance have no mention, and they say that some deaths occur during the rains and that their children are always sick.

In comparing Figure 1 with Figure 2, development workers soon begin to recognise the linkages to be made between agriculture, food, income, expenditure, labour, sickness and general well-being. They are also able to begin to appreciate the need for concern over the effects that increased pressures bring upon relationships between men and women. Gender, economic, psychological and physical well-being are linked through these charts and start to be accepted as given.

On a more immediate practical level of gender difference, development workers are shown two maps of another village, also in Sierra Leone. One was drawn by men, the other by women. Each map shows where the artists would like new wells to be dug. The men had drawn three separate wells in different corners of the village. The women had drawn one well in the middle of the village. The development workers are asked if they can explain the different choices.

It turned out that there were three separate clans in this village and the men thus automatically drew one well for each clan area. By contrast, the women thought first about the need for water and placed it centrally for all to use. The development workers are then asked what they should do, given that there are only enough people in the village to warrant the agency paying for one well there. Through discussion, they appreciate that the needs of the clan structure, perceived by the men of the village, need to be taken into account because of the decisions which would need to be taken on location, use and maintenance of the well: but that the women's readiness to share a well, for the sake of easy access to a safe source of water, will be a useful support to their planning needs.

A third illustration of the importance of recognising difference connects gender issues with age and 


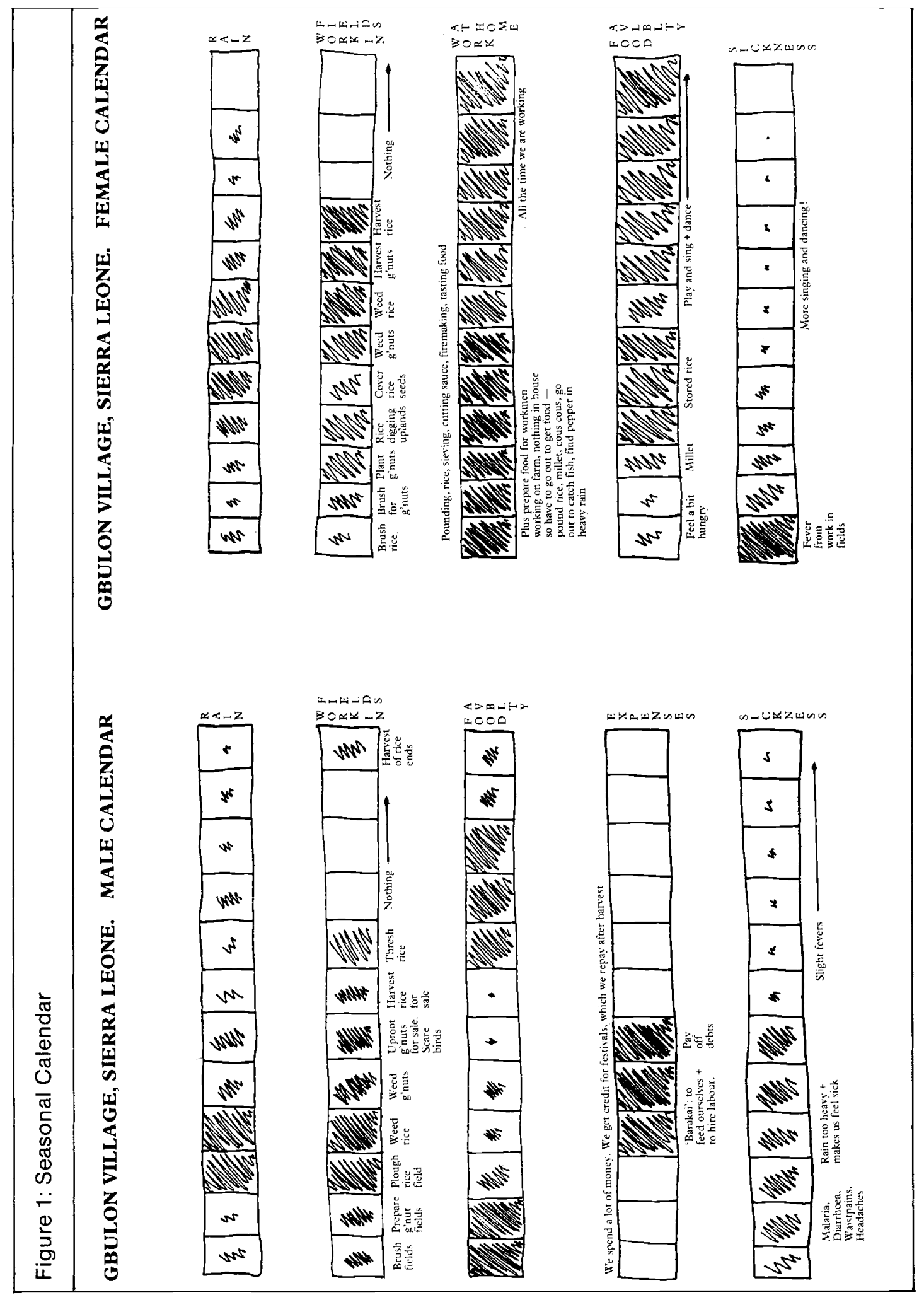




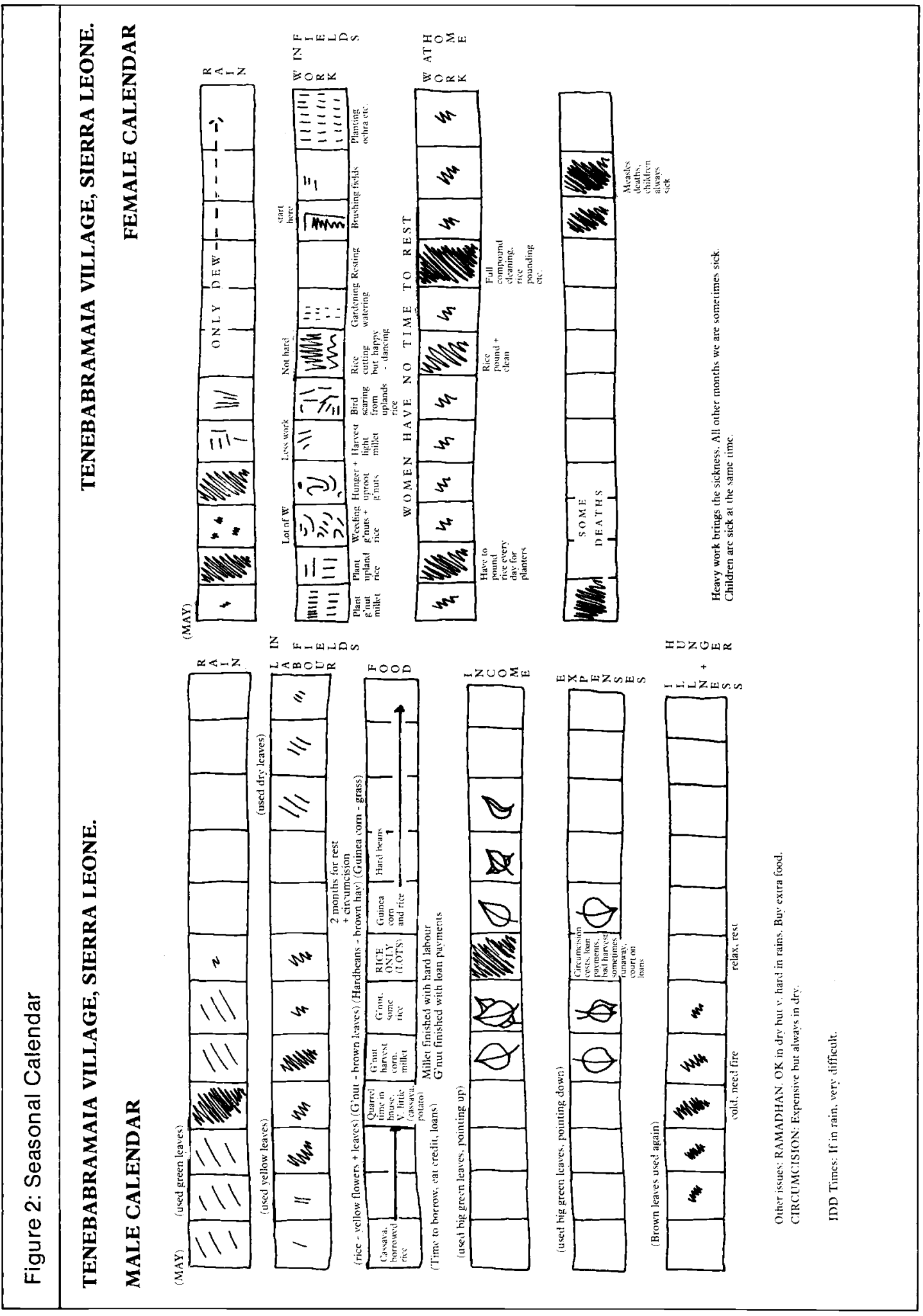


perceptions of poverty. Figure 3 shows a summary of perceptions of well-being and poverty in a village in Malawi. These perceptions were gathered through an exercise in socio-economic ranking. Three old women were asked to rank the households in their village (including female-headed households) in order of overall status or well-being. Three young men were asked to do the same and so were three old men. Each villager conducted the exercise individually. This chart compares the average opinions of the three separate groups. The most significant difference of opinion appears between those whom the old men consider the poorest in the village (female-headed households) and those considered poorest by the rest (old people with no support from their families). The development workers are encouraged to ask why the old men have placed the female-headed households at the bottom; and to consider once more the potential consequences of only listening to the opinions of one group in the village.

In these ways, a recognition of both intra-communal and inter-communal differences, and the clear need to analyse the consequences of those differences, is firmly established in the minds of the development workers. At the same time they start to appreciate the interconnectedness of different aspects of people's lives. The next section deals specifically with this matter.

\section{STEP TWO: HEALTH VERSUS WEALTH}

The most striking aspect of the RRA approach for health workers is the fact that all better-off members of communities, provided that some kind of curative care is locally available, place the need for access to a regular income well above the need for decent health services. Moreover, there is often no community recognition whatever of primary health care (PHC) as a health programme. Community health needs are focused on curative care and not on the preventive care which $\mathrm{PHC}$ has to offer. Villagers know perfectly well that when they have reasonable economic wherewithal, their health is, on the whole, reasonably good. They recognise that health care nowadays is essentially an economic commodity and, if they have the cash to pay, health problems are not normally the first priorities in their lives. Their health problems start to get out of hand when they grow poorer. Health and wealth are finely in balance. When people are poorer and cannot so readily afford drugs or treatment, health problems do start to come to the fore and are given much more priority. For people in distress, who have faced some kind of calamity, which necessitates immediate access to efficient curative care, health as well as wealth becomes a matter of urgency.

This realization is an important one, particularly for health workers. If they go into a village, as health workers, talking to villagers about their needs, they will indeed be told about health issues. But if they go in as a part of a multi-disciplinary team, using this type of approach, they will learn instead about people's own perceptions of the way in which well-being is connected to the rest of people's lives.

Such a realization can often be quite a shock to development workers who, having struggled through the system to complete a western education, learn that their expertise is often rather far removed from village experience or village needs. Western donors and NGOs often have a set blueprint agenda of health care, education or water programmes. Yet often what people themselves say they want is very different from what we prescribe. For them, life is clearly a continuum, linking agriculture and environment to general well-being. Our approach makes rather a nonsense of how they experience the world. Communities' health problems may often better be addressed through increased access to cash to pay for curative care than through $\mathrm{PHC}$ programmes.

Figure 4 shows the results of an exercise in problem priority matrix ranking with recently landless women in Bangladesh. The women were asked to name their main problems. A symbol for each problem mentioned was drawn on a separate card. Symbols were easily understood by all, such as coins for lack of money. The women were then asked to compare each problem with another, one by one, until an overall sequence of importance was established. The results demonstrate clearly the women's over-riding concern for economic wherewithal, future diminution of resources (the river bank on which they live), and lack of business opportunities. Health and medical issues are of much less importance to them. Even though these women are landless, their priorities still lie with economic concerns. It is envisaged that, unless their economic situation improves, their health will indeed begin to be affected and priority given to health problems will then increase. Yet the standard western agency approach might be to prioritise health care and education needs: and might well overlook the connection between good health and good economic well-being. Similar priorities are normally voiced by communities in Africa also, and it is time that they be listened to.

Not only do development workers tend to assume that issues such as health and education are far more pressing than they usually are for communities, it is regularly assumed that those health and education needs which are identified in village meetings will benefit everyone in the village. Yet normally, those who come to village meetings are not at all representative of everybody's needs. Instead, through this training, development workers recognise that those who do come are men rather than women and better off rather than poorer: also that they are often the village elders, 


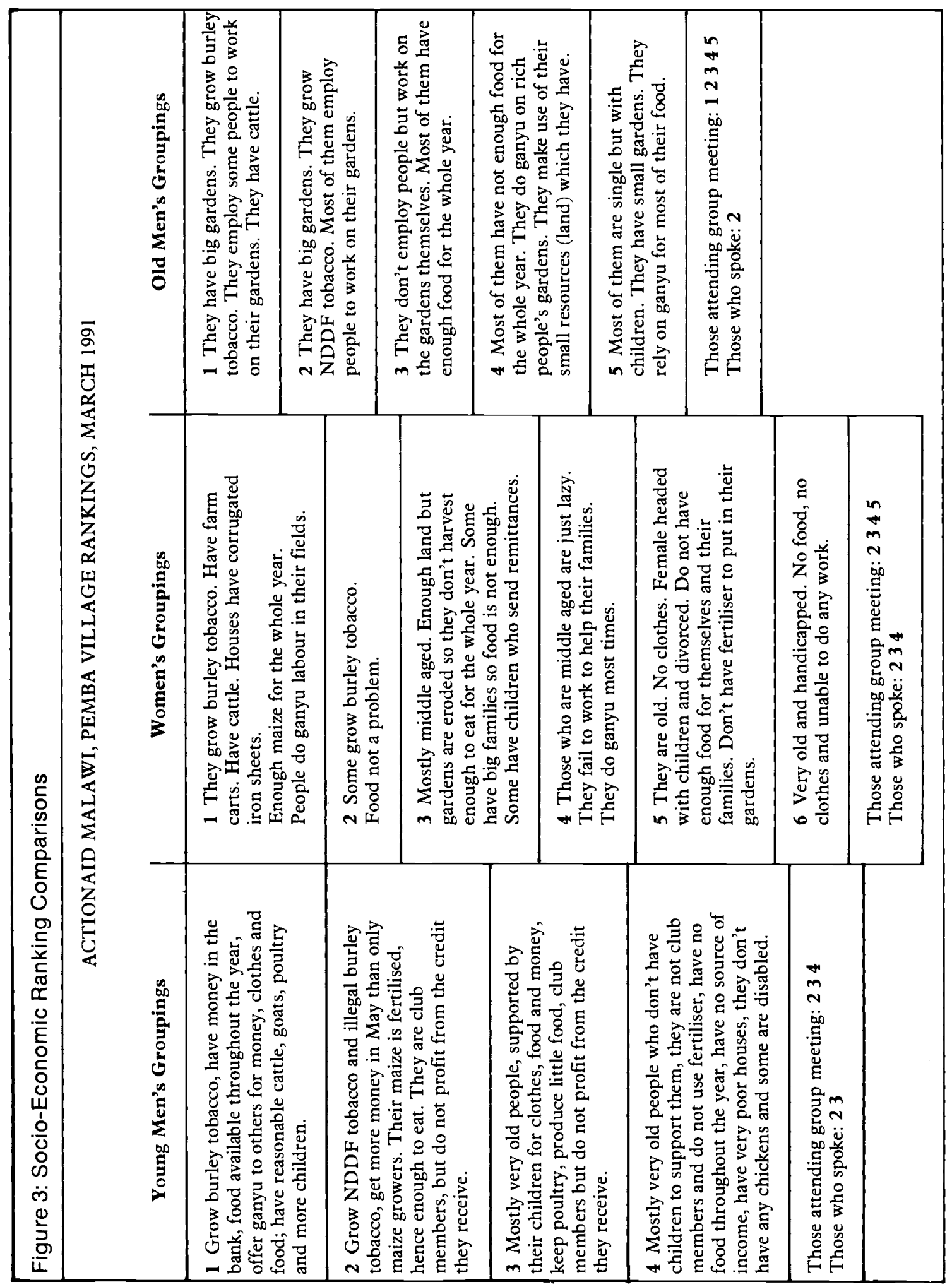


Figure 4: Priority Ranking of their Problems (Women) - Landless

ActionAid May 1991, Bangladesh

\begin{tabular}{|c|c|c|c|c|c|c|c|c|}
\hline Problems & $\begin{array}{c}\text { River } \\
\text { Erosion }\end{array}$ & $\begin{array}{l}\text { Economic } \\
\text { Problem }\end{array}$ & $\begin{array}{l}\text { Health and } \\
\text { Medical }\end{array}$ & Sanitation & $\begin{array}{c}\text { Lack of } \\
\text { Work for } \\
\text { the Women }\end{array}$ & $\begin{array}{c}\text { Lack of } \\
\text { Business } \\
\text { Opportunity }\end{array}$ & $\begin{array}{l}\text { Dowry } \\
\text { System }\end{array}$ & $\begin{array}{c}\text { Infertility } \\
\text { of Soil }\end{array}$ \\
\hline $\begin{array}{l}\text { Infertility } \\
\text { of Soil }\end{array}$ & $\begin{array}{l}\text { River } \\
\text { Erosion }\end{array}$ & Economic & Medical & Sanitation & $\begin{array}{l}\text { Work for } \\
\text { Women }\end{array}$ & Business & Dowry & $\mathrm{X}$ \\
\hline $\begin{array}{l}\text { Dowry } \\
\text { System }\end{array}$ & $\begin{array}{l}\text { River } \\
\text { Erosion }\end{array}$ & Economic & Medical & Sanitation & $\begin{array}{l}\text { Work for } \\
\text { Women }\end{array}$ & Business & $\mathrm{x}$ & $\mathrm{X}$ \\
\hline $\begin{array}{c}\text { Lack of } \\
\text { Business } \\
\text { Opportunity }\end{array}$ & $\begin{array}{l}\text { River } \\
\text { Erosion }\end{array}$ & Economic & Business & Business & Business & $\mathrm{X}$ & $\mathbf{X}$ & $\mathrm{X}$ \\
\hline $\begin{array}{l}\text { Lack of } \\
\text { Work for } \\
\text { Women }\end{array}$ & $\begin{array}{l}\text { River } \\
\text { Erosion }\end{array}$ & Economic & $\begin{array}{l}\text { Work for } \\
\text { Women }\end{array}$ & $\begin{array}{l}\text { Work for } \\
\text { Women }\end{array}$ & $\mathrm{X}$ & $\mathbf{X}$ & $\mathrm{X}$ & $\mathrm{X}$ \\
\hline Sanitation & $\begin{array}{l}\text { River } \\
\text { Erosion }\end{array}$ & Economic & Sanitation & $\mathrm{X}$ & $\mathrm{X}$ & $\mathrm{X}$ & $\mathrm{X}$ & $\mathrm{X}$ \\
\hline $\begin{array}{c}\text { Health and } \\
\text { Medical }\end{array}$ & $\begin{array}{l}\text { River } \\
\text { Erosion }\end{array}$ & Economic & $\mathrm{X}$ & $\mathrm{x}$ & $\mathrm{X}$ & $\mathrm{X}$ & $\mathrm{X}$ & $\mathrm{x}$ \\
\hline $\begin{array}{l}\text { Economic } \\
\text { Problem }\end{array}$ & Economic & $\mathrm{x}$ & $\mathrm{X}$ & $\mathrm{X}$ & $\mathrm{X}$ & $\mathbf{X}$ & $\mathrm{X}$ & $\mathrm{X}$ \\
\hline $\begin{array}{l}\text { River } \\
\text { Erosion }\end{array}$ & $\mathrm{X}$ & $\mathrm{X}$ & $\mathrm{X}$ & $\mathrm{X}$ & $\mathrm{X}$ & $\mathrm{X}$ & $\mathrm{X}$ & $\mathrm{X}$ \\
\hline \multicolumn{9}{|c|}{$\begin{array}{l}\text { CAUSES: } \\
\text { 1. In order to meet everyday necessities economic problem mu } \\
\text { 2. River erosion forced them to move again and again. } \\
\text { 3. Income will increase if they can do business. } \\
\text { 4. Income will increase if women get work. } \\
\text { 5. Women need good sanitation. } \\
\text { 6. If other problem solved dowry itself will not be a problem. } \\
\text { 7. Infertile land doesn't matter here because landless now. }\end{array}$} \\
\hline
\end{tabular}

and that the needs of younger people - and children are overlooked entirely.

In the exercise conducted in Malawi, illustrated in Figure 3, it was recognised that those talking in the meetings came predominantly from socio-economic groups 2 and 3 . It was then also recognised, on analysis, that a health clinic and a roof for the school building, which were identified as village needs at these meetings, were mostly of relevance only to the needs of those who talked at the meeting. The school roof would be of no relevance at all to the poorest of the village, who could afford neither the time nor the resources to send a child to school, or who were in any case at quite the wrong stage of their lives to benefit from schooling. The health clinic would be an unlikely intervention, given the relative proximity of a larger health centre. However for the poorest, transport and treatment costs and lack of time and support structures normally form a barrier to adequate health care. 
By collection and analysis of such information, development workers learn to see for themselves how easy it is to assume that we have consulted villagers, when in fact we have only scratched the surface of people's needs. The next section shows how further RRA techniques of data collection can help us to understand in much greater detail what people's health needs are and how they might begin to be addressed more effectively.

\section{STEP THREE: A BETTER UNDERSTANDING?}

Once development workers have learnt to recognise the importance of identifying and analysing difference; and once they perceive the value of adopting a multisectoral approach, the level of awareness of communities' needs can increase dramatically. Various different RRA techniques can be adopted and modified to this end.

Figure 5 shows a seasonal calendar of illness incidence and prevalence in Bangladesh, constructed by the landless women mentioned previously. Collection of information like this provides development workers with a clear opportunity to home in on specific times of the year and to provide appropriate health education, vaccination campaigns and so on at the times when they are of most relevance to people's lives. Such exercises could be taken further, to analyse how people rank different health problems in terms of severity, danger, effects on labour demand, time costs of caring, financial cost of treatment - or in terms of other characteristics, identified by communities themselves.

Figure 6 illustrates an exercise which asked the same Bangladeshi women to list various staple foodstuffs and to rank them in terms of characteristics identified as important by themselves. Such exercises often produce surprising results, such as the high value given by these women to wheat, compared with rice. Similar exercises could be used to compare preferences for different types of health care and they should be conducted of course with different groups within communities, to see if different key issues emerge according to gender, wealth or other factors.

A further technique of great potential use is illustrated in Figure 7. This technique is known as a 'Chapati Diagram' and the one illustrated is based on one which

Figure 5: Seasonal Calendar of IIIness

ActionAid Bangladesh, May 1991, Landless Women

\begin{tabular}{|c|c|c|c|c|c|c|c|c|c|c|c|c|}
\hline $\begin{array}{l}\text { Number of } \\
\text { Months }\end{array}$ & $\mathbf{B}$ & J & $\mathbf{A}$ & $\mathbf{S}$ & $\mathbf{V}$ & $\mathbf{A W}$ & $\mathbf{K}$ & $\mathbf{A G}$ & $\mathbf{P}$ & $\mathbf{M}$ & $\mathbf{F}$ & C \\
\hline Gastric & 00 & 00 & 00 & 00 & 00 & 00 & 00 & 00 & 00 & 00 & 00 & 00 \\
\hline Fever & - & - & 0 & $\begin{array}{l}00 \\
00 \\
00 \\
00\end{array}$ & $\begin{array}{l}000 \\
000 \\
000\end{array}$ & - & - & - & - & - & - & - \\
\hline Chicken Pox & $\begin{array}{c}0000 \\
0000 \\
0000 \\
0\end{array}$ & - & - & - & - & - & - & - & - & - & - & $\begin{array}{c}0000 \\
0000 \\
0000 \\
0\end{array}$ \\
\hline Diarrhoea & - & - & - & - & - & $\begin{array}{c}0000 \\
0000 \\
0000 \\
00\end{array}$ & $\begin{array}{l}000 \\
000 \\
000 \\
000\end{array}$ & - & - & - & - & - \\
\hline Goitre & 00 & 00 & 00 & 00 & 00 & 00 & 00 & 00 & 00 & 00 & 00 & 00 \\
\hline $\begin{array}{l}\text { Worms and } \\
\text { Anaemia }\end{array}$ & 00 & 00 & 00 & 00 & 00 & 00 & 00 & 00 & 00 & 00 & 00 & 00 \\
\hline
\end{tabular}


Figure 6: Food Preference Ranking

Food Ranking (Women) Kawner Char, Bangladesh, ActionAid, May 1991

\begin{tabular}{|l|c|c|c|c|c|c|}
\hline \multicolumn{1}{|c|}{ Name of Food } & Fish & Vegetables & Rice & Sweet Potato & Wheat & Dry Fish \\
\hline Low Price & 1 & 4 & 1 & 4 & 5 & 1 \\
\hline More Filling & 0 & 0 & 8 & 2 & 6 & 0 \\
\hline Available & 0 & 1 & 2 & 5 & 11 & 19 \\
\hline Total & 1 & 5 & 11 & & 1 \\
\hline $\begin{array}{l}\text { Wheat }=19 \\
\text { Sweet Potato }=11 \\
\text { Rice }=11 \\
\text { Vegetables }=5 \\
\text { Dry Fish }=1 \\
\text { Fish }=1\end{array}$
\end{tabular}

was also constructed by the landless women in Bangladesh. The exercise is carried out once more on the ground, using circles made of old newspaper and lines of sticks or chalk, to link or separate them. Each circle represents a different individual or group and the lines around them illustrate the sphere of influence of each or connections between them. The size of each circle reflects the power of each body. In this way, non-literate people can provide graphic illustration of the political structures within which they perceive themselves to operate. Whilst use of such techniques sometimes seems quite difficult and daunting for literate people, who are used to the powers of the pen, non-literate people have proved themselves most skilled in expressing themselves through this medium. The exercise was accompanied by a long and detailed discussion amongst the women, which revealed greatly detailed information about the political and economic structures and tensions experienced by the community.

Once again, it would be most important and valuable to compare the ways in which women would construct a chapati diagram of their village decision-making structures in comparison to men. We would be likely to find that women's powers of influencing decisions about western health care structures were rather less than those of men. Chapati diagram construction and problem priority ranking would also be useful ways of investigating women's alternative options for health care - western and traditional - both for themselves and for their children. Access to financial resources, for instance, to pay for certain health care, is often severely constrained by their access to their husband's resources. Such barriers may greatly influence their choices over what they do when sickness occurs. Yet there may also be alternative resources controlled solely by women, which could in some way be given support, thereby alleviating pressures on women to cope. Techniques such as those described here, would enable development workers to explore such options in a far more creative and dynamic manner than conventional questioning allows.

\section{STEP FOUR: A BETTER RESPONSE}

Some people worry that this approach advocates a complete dismissal of western knowledge of what can help. It is feared that, unless women express an interest in vaccination, for instance, or clean, safe drinking water, that such obviously beneficial interventions of these can have no place.

This is not the intention of people using such techniques. Instead the aim is rather to try to redress the balance between 'us' and 'them', so that the interaction between both sides is viewed as a dialogue rather than a monologue.

Development workers in the different projects where RRA exercises have been carried out have all commented on the enhanced community trust and cooperation which has resulted from the work. Similarly Eng et al (1990), were surprised by the increased understanding of health workers in Togo 
Figure 7: Chapati Diagram, Women, Bangladesh

ActionAid, May 1991

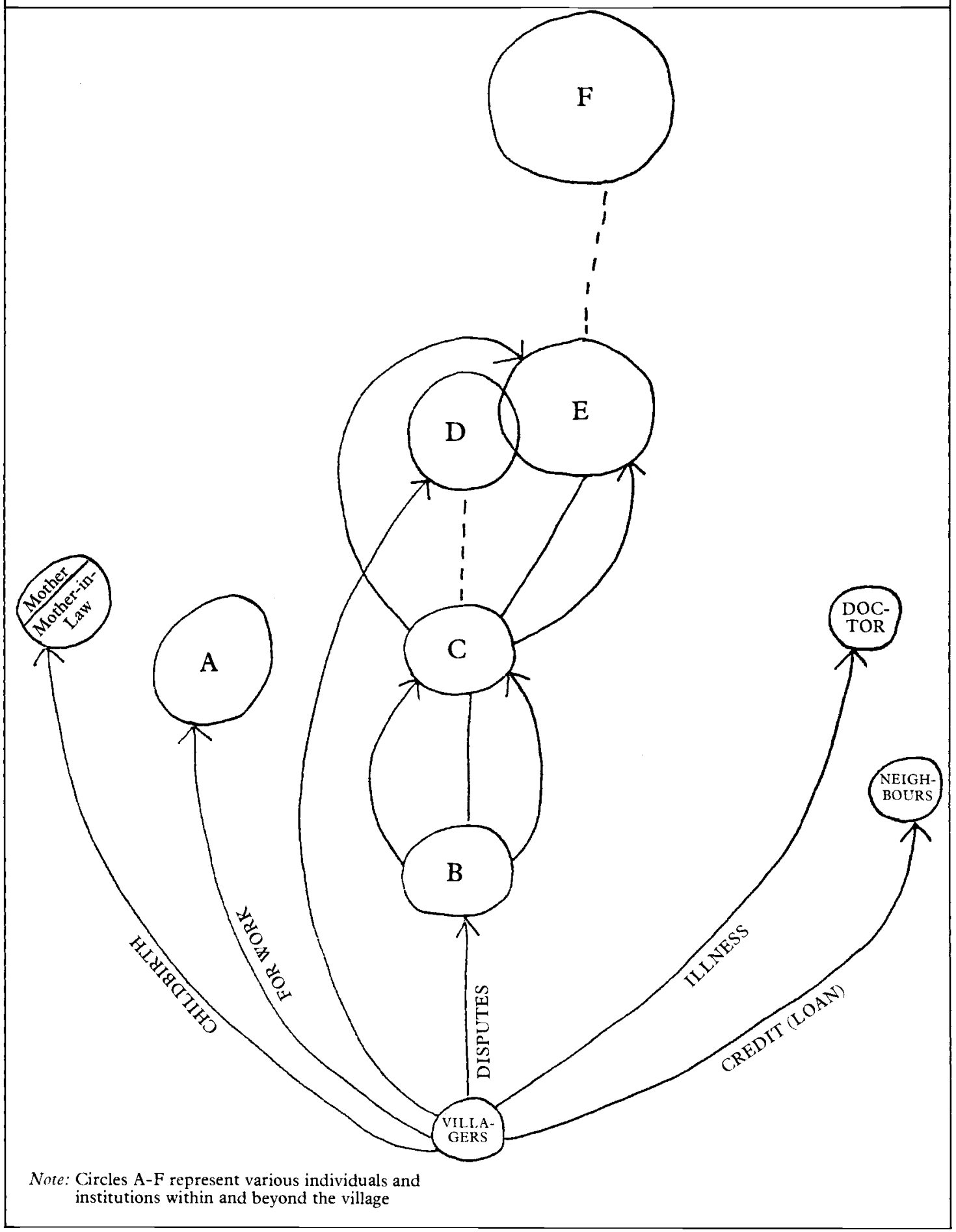


after they had been trained in focus group discussion techniques, as well as the greater uptake of western health services by the women whom they met with.

In particular, the increased empathy which is generated with villagers through using these techniques, has allowed development workers to begin to explore many sensitive issues which are never usually mentioned between villagers and development workers. These include gynaecological problems, STDs, extramarital relations, the stress of unemployment, wifebeating, greatly increased psychological illness, drug abuse, increased pregnancies and the plethora of other consequences of the severe economic problems affecting both men and women nowadays in most of the world. Development workers have begun to recognise also that these too are some of the health issues that are of real and deep concern to their potential clients.

RRA techniques rely a great deal on Freirian thinking. There are of course other techniques of communicating with people which are closely connected. But the active participation of villagers in graphic exercises of the sort described hęre provides, I believe, a particularly exciting breakthrough in tapping the knowledge of communities.

\section{CONCLUSION}

This article has briefly described a variety of different RRA techniques and the type of information which can be collected. Particular achievements of using RRA techniques in training development workers can be listed as follows:

- We could talk together about the differences between men, women, richer, poorer and so on as something obvious and non-threatening. They appreciated that different people have different perspectives, depending on the context; and that it is essential to their own task as development workers to understand this.

- We could understand that health is not just in a compartment on its own, but that it is affected by all kinds of other factors; and that it is essential to our work to develop a multi-sectoral team approach to health care development.

- We could see that people rarely prioritise health themselves, unless they are in distress. Otherwise, we could see that income, food security, access to and control of resources and benefits are often issues of far more importance than whether there was a health clinic there or not; and that this prioritisation is not ignorance but well founded.

- Finally, we could see that, once people are given the space, in small separate groups, to explain themselves and their needs to others, who are prepared to listen, they open up in a manner rarely seen in normal, conventional encounters. It was then that the real needs of well-being and all that that embraces truly began to be voiced.

The concept and methodology of RRA does appear to have significant potential in exploring issues concerning gender relations and health issues, within the wider context of community needs. Development workers have been deeply impressed by what they have learnt from this approach to their work. The question now facing health staff and others is how this new understanding can be incorporated into western health service delivery. I consider that employment of RRA techniques has notable potential in that area also.

\section{NOTES:}

For publication purposes it was necessary to typeset the diagrams in this article. Normally these would be handwritten and drawn freehand by fieldworkers.

Figure 2 appeared first in Welbourn 1991a.

Figure 3 appeared first in Welbourn 1991b, with kind permission of ActionAid Malawi.

Figures 4-7 are reproduced with kind permission of ActionAid Bangladesh from their recent RRA report.

\section{REFERENCES}

ActionAid Bangladesh, 1991, 'Report on the RRA of Kawner Char, Islampur Upozilla, Jamalpur District', Bangladesh

Eng, E., Gilk, D. and Parker, K., 1990, 'Focus-group methods: effects on village-agency collaboration for child survival', Health Policy and Planning, Vol 5 No 1: 67-76

IIED, 1991, RRA Notes, London

Welbourn, A., 1991a, 'The Socio-economic dimensions of poverty and ill-health, based on fieldwork in Sierra Leone, Uganda and Ghana. Liverpool School of Tropical Medicine

-1991b, 'RRA and the Analysis of Difference' in RRA Notes 